\title{
Biosorption of Cationic Dyes onto Cork Stopper Particles
}

\author{
Israa A. Al.Joboury ${ }^{1, *}$, and Shahlaa E.Ebrahime ${ }^{2}$ \\ ${ }^{1}$ Department of Environmental Engineering, University of Baghdad, Baghdad, Iraq, asraaahmed239@yahoo.com \\ ${ }_{2}^{2}$ Department of Environmental Engineering, University of Baghdad, Baghdad, Iraq, shahlaa.ebrahim@fulbrightmail.org \\ * Israa A. Al.Joboury asraaahmed239@yahoo.com \\ Published online: 31 August 2019
}

Abstract-In this study, cork stopper particles were used as a low cost biosorbent to remove the cationic dyes (Methylene blue (MB), Malachite green (MG), and Methyl violet (MV)) from simulated wastewater. Batch sorption experiments of components were conducted as a function of $\mathrm{pH}$, sorbent dosages, contact time, agitation speed, and particle size to optimize the best conditions for maximum removal efficiencies of dyes. The experimental data fitted slightly best to the Langmuir isotherm model than to Freundlich and Temkin isotherm model. The experimental data proved that the adsorption kinetic of MB, MG, and MV could be described by a pseudo-second order model. The results indicate that cork adsorbs dyes efficiently and could be employed as a low-cost alternative in wastewater treatment for the removal of cationic dyes.

Keywords- Batch sorption; Kinetic models; Isotherm models; cork stopper particles; Methylene blue; Malachite green; Methyl violet.

\section{Introduction}

Surface water contamination by pollutants is common in highly industrialized countries due to direct discharge of industrial effluents water bodies or by precipitation of air borne pollutants into surface waters. Of the pollutants released along with industrial effluents, dyes are the most easily detected since dyes are inherently highly visible, meaning that concentrations as low as $0.005 \mathrm{mg} / \mathrm{l}$ will capture the attention of the public and the authorities [31]. Apart from the aesthetic problems caused by dyes, the greatest environmental concern with dyes is their absorption and reflection of sunlight entering the water, which interferes with the growth of bacteria to levels insufficient to biologically degrade impurities in the water [6]. Colored effluents can cause problems in several ways: dyes can have acute and chronic effects on exposed organisms depending on the exposure time, and dye concentration; dyes absorb and reflects sunlight entering water and so can interfere with the growth of bacteria and hinder photosynthesis in aquatic plants [37]. Majority of these dyes are synthetic in nature and are usually composed of aromatic rings in their structures, which makes them carcinogenic and mutagenic [26], inert and non-biodegradable when discharged in to waste streams [18]. Major research has been undertaken to develop new promising materials for dye removal. Malachite green $(\mathrm{C} 23 \mathrm{H} 25 \mathrm{ClN} 2,364.91 \mathrm{~g} /$ mole, $614 \mathrm{~nm})$ is a green crystal powder with lustre, highly soluble in water. It acts as a respiratory enzyme poisoning fish. It decreases food intake, causes damage to liver, kidney and is infectious to skin, eyes and bones. Methylene blue (C16H18ClN3S.3H2o, $373.90 \mathrm{~g} / \mathrm{mole}, 668 \mathrm{~nm}$ ) is a dark green powder causes nausea, hypertension, haemolysis and respiratory distress [35]. Methyl violet $(\mathrm{C} 24 \mathrm{H} 28 \mathrm{ClN} 3$, $393.95 \mathrm{~g} /$ mole, $590 \mathrm{~nm}$ ) may cause irritation to the respiratory tracks, vomiting, diarrhea, pain, headaches and dizziness. Long term exposure may cause damage to the mucous membranes and gastrointestinal tract [15]. Various techniques, such as adsorption [5,23], membrane process [20], coagulation [27], flocculation [38], photodecomposi- tion [16], electrochemical oxidation [33], etc., have been used for the removal of dyes from waste water. Among these techniques, adsorption has been proven to be the most potential one due to its flexibility, simplicity of design, high efficiency and ability to separate wide range of chemical compounds [9]. optimization of adsorption methods should be carried out, first of all, by choosing or developing inexpensive adsorbents selective to the contaminants to be removed. There are many factors that affect the decision of choosing an adsorbent for removal of pollutants from water such as: economical factor (cost of the adsorbent), abundance, availability, and effectiveness of the adsorbent [34]. Various types of materials have been used as adsorbents, such as activated carbon, manganese oxide, silica gel, fly ash, wollastonite, lignite, peat, soil, alumina, rutil, geothite, hematit, 
bentonit, sphalerit, anatase, red mud, mica, illite, kaolinite, and clays [4]. Cork is the phellem layer of bark tissue that is harvested for commercial use, primarily from the cork oak. Due to its peculiar morphological structure and chemical composition, cork presents unique properties, such as hydrophobicity, low density, low thermal conductivity, acoustic insulation, chemical stability, and durability [8][13][22]. It is mainly used for stoppers in juice industry due to impermeable and compressible properties. Cork is also used as insulation material in building and space vehicles due to its low thermal conductivity [30]. Cork also used in shoes insole and adsorption of pollutants as an adsorbent [32]. The interaction of cork with organic pollutants, which are essentially hydrophobic, can be explained by its structure, especially its aromatic domain of suberin and lignin. Being hydrophobic itself, cork has an advantage of affinity over other natural materials for the removal of organic pollutants [11]. Cork oak represents the advantages of being "the only tree whose bark can regenerate after harvesting, making cork a true eco-friendly material, as it is a renewable resource [12].in this study, use of natural, economic, and environmental friendly biosorbent to remove $\mathrm{MB}, \mathrm{MG}$, and $\mathrm{MV}$ was investigated.

\section{Materials and Methods}

\subsection{Preparation of cork stopper particles}

The cork stopper particles used in this study was obtained from local markets. The collected biomaterial was extensively washed with tap water to remove soil and dust. Distilled water was used to wash the cork stoppers and after that dried in an oven (Type BBDE; S/N 20-601148, Korea) at $80^{\circ} \mathrm{C}$ for 10 hours. Dry biomass was cracked and grinded with grinder. The product was sieved through a 1000 and $75 \mu \mathrm{m}$ diameter mesh. The geometric mean diameter is given by $d_{g m}=\left(d_{1} d_{2}\right)^{1 / 2}$ where $d_{1}$ : is the diameter of lower sieve on which the particles are retained and $\mathrm{d}_{2}$ : is the diameter of the upper sieve through which the particles pass [7]. Fig.1 shows the pictures of natural biosorbent (cork stoppers) that used in this study, (a) before and, (b) after grinded and sieved to $110 \mu \mathrm{m}$ diameter.

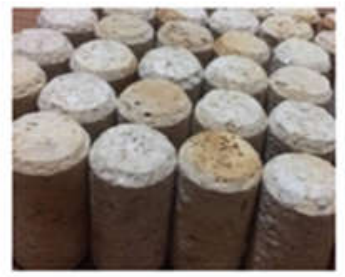

(a) Before grinding

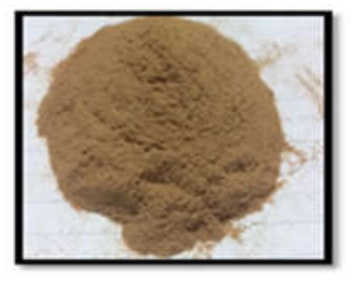

(b) After grinding and sieving
Figure 1: A sample of natural and grinded cork stopper particles.

\subsection{Stock solution preparation}

Stock solution of three cationic dyes (Methylene Blue, Malachite Green, Methyl Violet) was prepared by dissolving accurately weighed dye powder in distilled water at a concentration of $1 \mathrm{~g} / \mathrm{l}$ and left overnight to make the dye powder fully dissolved. Dye solution then diluted to the desired solutions concentration that used for the batch experiments.

\subsection{Equilibrium isotherm}

Equilibrium isotherm studies were conducted to optimize the design of biosorption system for dyes removal from effluents. In addition to that, data series was constructed from which biosorption isotherm could be fitted. The same procedure in the above section was utilized with initial adsorbates concentrations of $50 \mathrm{mg} / \mathrm{l}$, agitation speed (200) rpm, contact time (180) $\mathrm{min}$ and particle size $<1 \mathrm{~mm}$. Different doses of biosorbents were used starting from 0.1 $1.4 \mathrm{~g} / 100 \mathrm{ml}$ to obtain equilibrium isotherm curve. The final concentration of the dyes solution $(C \mathrm{e})$ at equilibrium was measured to calculate the adsorbed amount of dyes at final equilibrium ( $q$ e) using Eq. (1):

$$
q_{e}=\frac{V\left(C_{o}-C_{e}\right)}{m}
$$

Where

$\mathrm{qe}=$ the equilibrium biosorption capacity $(\mathrm{mg} / \mathrm{g})$; Co and $\mathrm{Ce}=$ the initial and equilibrium adsorbate concentrations in water $(\mathrm{mg} / \mathrm{l})$, respectively; $\mathrm{V}=$ the volume of used solution (l); and $\mathrm{m}=$ the mass of used adsorbent ( $\mathrm{g}$ ). The experimental data were fitted with three isotherm models, Langmuir, Freundlich and Temkin models. These models are represented in Table.1. 
Table 1: Division, genus, species and weighting percentage of collected algae.

\begin{tabular}{|c|c|c|c|c|}
\hline Model & Nonlinear form & Linear form & Plot & Ref \\
\hline \multirow[t]{2}{*}{ Langmuir } & $q_{e}=\frac{q_{m} b_{e}}{\left(1+b C_{e}\right)}$ & $\frac{1}{\mathrm{q}_{\mathrm{e}}}=\frac{1}{\mathrm{q}_{\mathrm{m}}}+\frac{1}{\mathrm{~b} \mathrm{q}_{\mathrm{m}}} * \frac{1}{\mathrm{C}_{\mathrm{e}}}$ & $\frac{\mathrm{Ce}}{\mathrm{qe}} \mathrm{VS} C e$ & \multirow[t]{2}{*}{ [28] } \\
\hline & \multicolumn{3}{|c|}{$\begin{array}{l}\mathrm{q}_{\mathrm{m}} \text { is the maximum sorption capacity for monolayer coverage, }(\mathrm{mg} / \mathrm{g}) \text {; } \\
\mathrm{b} \text { is the constant related to the affinity of the binding site, }(\mathrm{L} / \mathrm{mg}) \text {. }\end{array}$} & \\
\hline \multirow{2}{*}{ Freundlich } & $\mathrm{q}_{\mathrm{e}}=\mathrm{KC}_{\mathrm{e}}^{1 / \mathrm{n}}$ & $\ln q_{e}=\ln K+\frac{1}{n} \ln C_{e}$ & $\operatorname{Ln} \mathrm{q}_{\mathrm{e}} \mathrm{VS} \ln \mathrm{C}_{\mathrm{e}}$ & \multirow{2}{*}{ [29] } \\
\hline & $\begin{array}{l}\mathrm{K} \text { is constant indicativ } \\
(\mathrm{mg} / \mathrm{g})(\mathrm{L} / \mathrm{mg})^{1 / \mathrm{n}} ; 1 / \mathrm{n} \mathrm{i}\end{array}$ & $\begin{array}{l}\text { a relative adsorption capa } \\
\text { tant indicative of the inten }\end{array}$ & $\begin{array}{l}\text { of the adsorbent, } \\
\text { of the adsorption. }\end{array}$ & \\
\hline \multirow{2}{*}{ Temkin } & $\mathrm{q}_{\mathrm{e}}=\frac{\mathrm{RT}}{\mathrm{b}} \ln \left(\mathrm{K}_{\mathrm{T}} \mathrm{C}_{\mathrm{e}}\right)$ & $\mathrm{q}_{\mathrm{e}}=\mathrm{B}_{1} \ln \mathrm{K}_{\mathrm{T}}+\mathrm{B}_{1} \ln \mathrm{C}_{\mathrm{e}}$ & $\mathrm{C}_{\mathrm{e}} \mathrm{VS} \mathrm{LnC} \mathrm{L}_{\mathrm{e}}$ & {$[25]$} \\
\hline & \multicolumn{4}{|c|}{$\begin{array}{c}\mathrm{B}_{1}=\mathrm{RT} / \mathrm{b} ;(\mathrm{R}) \text { is the universal constant }(8.314 \mathrm{~J} / \mathrm{mol} . \mathrm{K}), \mathrm{b} \text { is the Temkin constant and } \mathrm{T} \text { is } \\
\text { the absolute temperature }(\mathrm{K}) .\left(\mathrm{K}_{\mathrm{T}}\right)(\mathrm{l} / \mathrm{mg}) \text { is the equilibrium binding constant } \\
\text { corresponding to the maximum binding energy and the constant } \mathrm{B}_{1}(\mathrm{KJ} / \mathrm{mole}) \text { is related to } \\
\text { the heat of adsorption. }\end{array}$} \\
\hline
\end{tabular}

\subsection{Fourier Transform Infrard analysis (FT-IR)}

The FT-IR spectra of cork stopper particles before and after $\mathrm{MB}, \mathrm{MG}$ and $\mathrm{MV}$ biosorption was examined to identify the functional groups which are responsible for dyes uptake and frequency changes of the functional groups in the biosorbent. In order to have a sample of cork stopper particles after dyes biosorption on its surface, the following experiment was carried out:

The best weight of dry (cork stopper particles) was contacted with $100 \mathrm{ml}$ of $50 \mathrm{mg} / \mathrm{l}$ of $\mathrm{MB}$ concentration in a volumetric flask. The MB solution was adjusted to best $\mathrm{pH}$ value and particle size. The sample was left on a shaker for $240 \mathrm{~min}$ at best agitation speed then, the sample was filtered through Whatman No. 542 filter paper. The supernatant was discarded and the biomass of cork stopper particles on filter paper was left to dry. Dried sample was collected and analyzed by FT-IR spectrophotometer (type IRPRESTIGE-2; Shimadzu 8000, Jaban) in the laboratory of organic chemistry / University of Al Nahrain. The same experiment with best conditions of biosorbent dosage, $\mathrm{pH}$ , particle size, agitation speed, and contact time was applied with MG and MV in order to obtain the required samples.

\section{$2.5 \quad$ Kinetic experiments}

The external mass transfer $\left(\mathrm{k}_{\mathrm{f}}\right)$ was obtained by using a well mixed batch contactor. In this step a known weight of adsorbent is mixed with a constant volume of solutions. This solution was placed in 2 liters Pyrex beaker. A 2- bladed stainless steel axial flow impellers (Wiggen Hauser, Germany) was fixed at the centers of the beaker. The experimental procedure was as follows: three beakers were used one of them was filled with 1.0 liter of MB solution of $50 \mathrm{mg} / \mathrm{l}$ concentration, the second filled with 1.0 liter of $\mathrm{MG}$ and the third filled with 1.0 liter of MV solution of 50 $\mathrm{mg} / \mathrm{l}$ at best $\mathrm{pH}$. The agitation started before adding the biosorbent. At zero time, an accurate mass of biosorbent was added. The biosorbent suspensions were stirred for (240) min and samples were collected and filtered through a whatman filter No.542. The filtrates were analyzed using Spectrophotometer UV.

The optimum speed was obtained by repeating the experiments for $\mathrm{MB}, \mathrm{MG}$ and $\mathrm{MV}$ with different agitation speeds $(200,400,600$ and $1000 \mathrm{rpm})$.

The necessary dosages of dried biomass to reach equilibrium concentrations of $\mathrm{C} / \mathrm{C}_{0}=0.05,(95 \%$ removal efficiency) were calculated from isotherms and balances equations as follows (in case of Langmiur model): [3]

$$
\begin{gathered}
q_{e}=\frac{V_{L}\left(C_{o}-C_{e}\right)}{W_{O}}=\frac{q_{m} b C_{e}}{1+b C_{e}} \\
W_{O}=\frac{V_{L}\left(C_{o}-C_{e}\right)\left(1+b C_{e}\right)}{\left(q_{m} b C_{e}\right)}
\end{gathered}
$$

\subsection{Pseudo-first order kinetic model}

The Pseudo-first order kinetic model was the first equation for the bisorption of liquid/solid systems based on solids 
capacity. It is widely used sorption for the sorption of solutes from liquid solutions and can be presented through the following equation: [17]

$$
\frac{d q_{t}}{d t}=K_{L}\left(q_{e q}-q_{t}\right)
$$

Integrating linearize (4) with the conditions; $" \mathrm{t}=0$ to $\mathrm{t}=\mathrm{t}$ and $\mathrm{q}_{\mathrm{t}}=0$ to $\mathrm{q}_{\mathrm{t}}=\mathrm{q}_{\mathrm{t}}$ ", gives:

$$
\ln \left(\frac{q_{e q}}{q_{e q-q_{t}}}\right)=K_{L} t
$$

qeq"the amount of adsorbat adsorbed at equilibrium $(\mathrm{mg} / \mathrm{g})$ "; $\mathrm{q}_{\mathrm{t}}$ "the amount of adsorbat adsorbed at time $\mathrm{t}$ $(\mathrm{mg} / \mathrm{g})$ "; and $\mathrm{K}_{\mathrm{L}}$ "the equilibrium rate constant of pseudofirst order sorption $\left(\mathrm{min}^{-1}\right)$ ". Equation (5) could rearrange to get a linear form:

$\ln \left(q_{e q-} q_{t}\right)=\ln q_{e q-}\left(K_{L} t\right)$

In order to fit equation (8), the equilibrium capacity $\left(\mathrm{q}_{\mathrm{eq}}\right)$ must be recognized to experimental data. The values of $\ln \left(\mathrm{q}_{\mathrm{eq}}-\mathrm{q}_{\mathrm{t}}\right)$ against $\mathrm{t}$ may be plotted from which $\mathrm{k}_{\mathrm{L}}$ and $\mathrm{q}_{\mathrm{eq}}$ represent the slope and intercept respectively".

\subsection{Pseudo-second order Model}

The pseudo-second-order model assumes that the depleting of the site of adsorption is proportional to the square number of unused sites. There are several assumptions explained the pseudo-second order kinetic model [19]

- A monolayer of adsorbate is represented on the surface of adsorbent .

- The adsorption energy for each adsorbent is equally based on surface coverage .

- The adsorption takes place on sites and no interactions between adsorbents .

The equation may be represented as:

$$
\frac{d q_{t}}{d t}=k_{s}\left(q_{e q-} q_{t}\right)^{2}
$$

$\mathrm{k}_{\mathrm{s}}$ "the rate constant of adsorption (g/mg .min)", $\mathrm{q}_{\mathrm{eq}}$ "the amount of pollutant adsorbed at equilibrium (mg/g)", $\mathrm{q}_{\mathrm{t}}$ " amount of adsorbate on the surface of the adsorbent at any time $\mathrm{t},(\mathrm{mg} / \mathrm{g}) "$.

Rearrangement of equation (7) gives:

$$
\frac{d q_{t}}{\left(q_{e q-}-q_{t}\right) 2}=k_{s} d t
$$

The boundary conditions were $" \mathrm{t}=0$ to $\mathrm{t}=\mathrm{t}$ and $\mathrm{q}_{\mathrm{t}}=0$ to $\mathrm{q}_{\mathrm{t}}=\mathrm{q}_{\mathrm{t}}$ "; the integrated form of equation (8) becomes:

$$
\frac{1}{q_{e q-} q_{t}}=\frac{1}{q_{e q}}+k_{s} t
$$

Which is the integrated rate law for a pseudo-second order reaction Equation (9) can be rearranged to obtain:

$$
q_{t}=\frac{1}{\frac{1}{k_{s} q_{e q}^{2}}+\frac{t}{q_{e q}}}
$$

Which has a linear form of

$$
\frac{1}{q_{t}}=\frac{1}{k_{s} q_{e q}^{2}} \frac{1}{t}+\frac{1}{q_{e q}}
$$

The values of $1 / q_{t}$ against $1 / t$ plotted and the values of $k_{s}$ and $\mathrm{q}_{\mathrm{eq}}$ represent the slope and intercept of the plot, respectively.

\subsection{Intra-particle diffusion model}

It may be represented as [36]:

$$
q_{t}=k_{i d} t^{1 / 2}+\mathrm{C}
$$

Where: $\mathrm{q}_{\mathrm{t}}(\mathrm{mg} / \mathrm{g})$ "the adsorbed amount at time $\mathrm{t}(\mathrm{min})$ ", $\mathrm{K}_{\mathrm{id}}$ "the rate constant of intra-particle diffusion $\left(\mathrm{mg} / \mathrm{g} \mathrm{min}{ }^{1 / 2}\right)$ ", $\mathrm{C}$ "(mg/g) the value of intercept which gives an idea about the boundary layer thickness", i.e. "the larger intercept increased the boundary layer effects.

\subsection{Elovich kinetic model}

A widely used equation to describe the kinetics of chemical adsorption is the elovich equation [10]:

$$
\frac{d q}{d t}=a \exp \left(-\bar{b} q_{t}\right)
$$

Where a (mg/g.min) and $\bar{b}(\mathrm{~g} / \mathrm{mg})$ are parameters of the equation. The parameter ais regarded as the initial rate because $\mathrm{dq} / \mathrm{dt} \rightarrow \mathrm{a}$ as $\mathrm{q} \rightarrow 0$ and the parameter $\overline{\mathrm{b}}$ is related to the extent of surface coverage and activation energy for chemical adsorption. Given that $\mathrm{q}=0$ at $\mathrm{t}=0$, the integrated form of equation (13) becomes:

$q_{t}=\left(\frac{1}{\bar{b}}\right) \ln \left(t+t_{0}\right)-\left(\frac{1}{\bar{b}}\right) \ln t_{0}$

Where $t_{0}=1 / a \bar{b}$. If $t>>t_{0}$, equation (14) is simplified as:

$q_{t}=\left(\frac{1}{\bar{b}}\right) \ln (a b)+\left(\frac{1}{\bar{b}}\right) \ln t$

The application of the Elovich equation in liquid phase adsorption is gaining in popularity [11][19].

\subsection{Fractional power kinetic model}

$$
q_{t}=K t^{x}
$$

Where $\mathrm{q}_{\mathrm{t}}$ is the amount of metal $(\mathrm{mg} / \mathrm{g})$ sorbed at time $\mathrm{t}$ and $x$ the rate constant of power function $\left(\mathrm{min}^{-1}\right) . \mathrm{K}$ is constant of power function model $(\mathrm{mg} / \mathrm{g})$. The model described the time-dependent metal on sorbent as the value of constant $x$ was less than $1[10]$.

Equation (16) can be rearranged to obtain equation (17), which has a linear form:

$\ln \left(q_{t}\right)=\ln (K)+x \ln (t)$ 


\section{Experimental Work}

\subsection{Effect of $p H$}

The effect of $\mathrm{pH}$ on dye removal is studied by varying the $\mathrm{pH}(2,3,4,5,6,7$ and 8$) .100 \mathrm{ml}$ of the dye solution (MB, $\mathrm{MG}$ and $\mathrm{MV}$ ) with $50 \mathrm{mg} / \mathrm{l}$ initial concentration was placed in seven-250ml volumetric flask containing $1 \mathrm{~g}$ of biosorbent for each dye. The $\mathrm{pH}$ of the dye solutions were adjusted to a desired $\mathrm{pH}$ using $0.1 \mathrm{~N} \mathrm{HCl}$ and/or $0.1 \mathrm{~N}$ $\mathrm{NaOH}$. These solutions were shaken using thermostatic shaker (Type SI-600R, Korea) and agitated continuously for 180 minute and $200 \mathrm{rpm}$ at room temperature. The solutions were filtered and analysed. The $\mathrm{pH}$, giving the maximum dyes removal efficiency, was selected and utilized for the subsequent biosorption studies.

\subsection{Effect of contact time}

The removal of (MB, MG, and MV) was also studied as a function of contact time. Different times were studied within the range (30-240) $\mathrm{min}$. $100 \mathrm{ml}$ of dye solution with $50 \mathrm{mg} / 1$ initial concentration was placed in eight $-250 \mathrm{ml}$ volumetric flasks for each dye. The times in which no extra $\mathrm{MB}, \mathrm{MG}$ and $\mathrm{MV}$ dyes removal can be attained were considered as the best contact times.

\subsection{Effect of agitation speed}

The process of biosorption also responds to the speed of agitation of the rotary shaker. The optimum agitation speeds was investigated to maximize the contact time between dyes and the biosorption site of biosorbent during equilibrium. To investigate the effects of agitation speeds on the (Methylene Blue, Malachite Green and Methyl Violet) removal efficiency, five different agitation speeds of rotary shaker $(100,150,200,250$ and $300 \mathrm{rpm})$ were employed and the same procedure stated in section (2.3.1) was repeated with constant adsorbent mass, $\mathrm{pH}$, and solute concentration. The agitation speed, giving the maximum dyes removal efficiency, was selected as the best for the subsequent biosorption studies.

\subsection{Effect of biosorbent does}

The effect of biosorbent dosage on the bisorption of dyes (Methylene Blue, Malachite Green and Methyl Violet) is studied by varying the mass of biosorbent from 0.1 to $1.4 \mathrm{~g}$. $100 \mathrm{ml}$ of dye solutions with $50 \mathrm{mg} / 1$ initial concentration and $\mathrm{PH}=3$ was placed in ten-volumetric flask containing $(0.1,0.2,0.3,0.4,0.6,0.7,0.85,1,1.2$, and 1.4) $\mathrm{g}$ for each dye. These solutions are shaken using thermostatic shaker (Type SI-600R, Korea) at room temperature, Then the solutions were filtered and analysed using spectrophotometer UV device to find the amount of dye removed by the biosorbent cork. The mass of biosorbent dose, giving the maximum dyes removal efficiency, was selected and utilized for the subsequent biosorption studies.

\subsection{Effect of particle size}

By using the biomass of different particle size, the process of biosoiption of different dyes was studied. The experiment were carried out for four different particle sizes (0.075-0.15, 0.25-0.3,0.5-0.6, and 0.6-1) mm under best other parameters $\mathrm{pH}$, biosorbent dosage, agitation speed, and contact time.

\section{Result and discussion}

\subsection{Effect of $\mathrm{pH}$}

The biosorption behavior of $\mathrm{MB}, \mathrm{MG}$, and $\mathrm{MV}$ on cork was studied using various initial $\mathrm{pH}$ varying from 2 to 8 . The relation between the removal efficiency of $\mathrm{MB}, \mathrm{MG}$, and $\mathrm{MV}$ dyes and different $\mathrm{Ph}$ values of the aqueous solutions are shown in fig.2. From this figure it can be seen that the removal efficiency increase suddenly within $\mathrm{pH} 3$ and then slowly decrease as the $\mathrm{pH}$ of solution increase to 8. Maximum MB, MG and MV removal was $96.4 \%$, $95.5 \%$ and $95.8 \%$ respectively at $\mathrm{pH} 3$. Lower removal at $\mathrm{pH}$ values lower than 3.0 maybe due to the dissolution of adsorbent. At higher $\mathrm{pH}$, the decrease in the positive charge of adsorbent surface sites can cause a decrease in the adsorption [1].

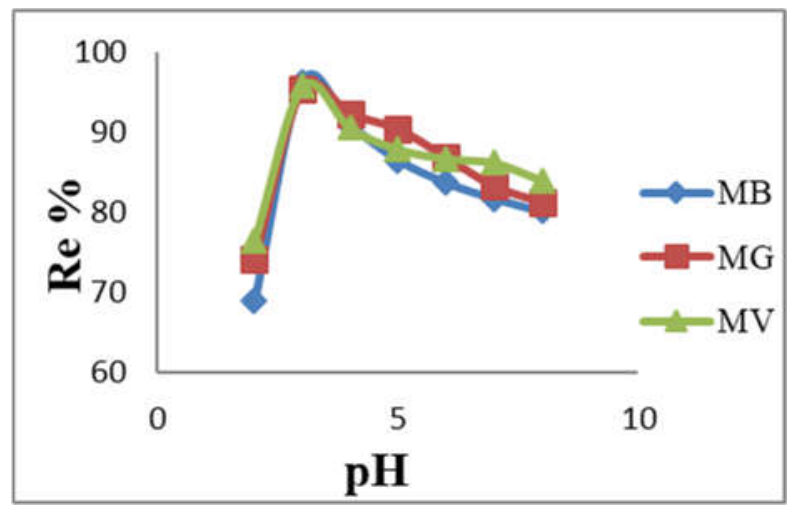

Figure 2: Percentages of $\mathrm{MB}, \mathrm{MG}$, and $\mathrm{MV}$ removal efficiency onto cork stopper particles at different $\mathrm{pH}$ values, $\left(\mathrm{C}_{0}=50 \mathrm{mg} / \mathrm{l}, \mathrm{W}=1 \mathrm{~g}\right.$, time $=180 \mathrm{~min}$, particle size $<1 \mathrm{~mm}$ )

\subsection{Effect of contact time}

The percentage of $\mathrm{MB}, \mathrm{MG}$ and $\mathrm{MV}$ adsorbed was estimated at different contact time in single system at constant other parameters; including $\mathrm{pH}=3$, dose of biosorbent $=(1,1.2,1.2) \mathrm{g}$, agitation speed $=(200,250) \mathrm{rpm}$ and particle size $<1 \mathrm{~mm}$. Fig. 3 denotes the relation between the removal efficiency and several contact time. It was observed that the MB, MG and MV biosorption increase as the contacts time increase and it remains stable after achieving equilibrium. This may be due to the availability of a large surface area of the cork stopper particles at the early stages of the biosorption process. As the sites of the surface biosorption became depleted, the uptakes rate is managed by the rates at which the adsorbate 
is moved from the exterior to the interior sites of the biosorbent particles. The highest removal efficiencies of MB, MG, and MV were $98.32,97.6$ and $98 \%$ respectively obtained after (240) min of shaking time. The results agrees with the findings obtained by $[2,21]$.

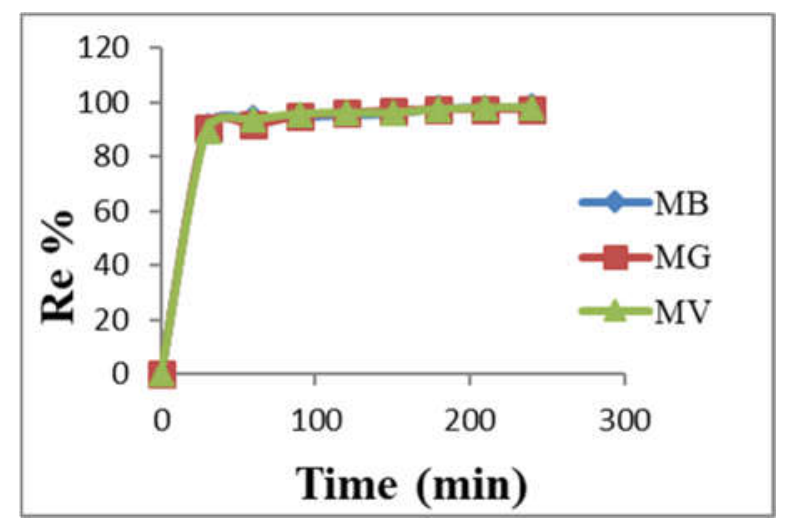

Figure 3: Percentage of $\mathrm{MB}, \mathrm{MG}$ and $\mathrm{MV}$ removal efficiency at different contact time $\left(\mathrm{C}_{0}=50 \mathrm{mg} / \mathrm{l}, \mathrm{W}=\right.$ $(1,1.2), \mathrm{pH}=3$, and $\mathrm{rpm}=(200,250)$, particle size $<1 \mathrm{~mm})$.

\subsection{Effect of agitation speed}

Fig.4 shows the relation between the removal efficiencies of $\mathrm{MB}, \mathrm{MG}$, and $\mathrm{MV}$ onto cork stopper particles at different agitation speeds. It was noted that "the removal efficiency of all dyes increased continuously as the agitation speeds increased. This is due to the fact that, a higher agitation speed reduced the film thickness and finally reduces film resistance. The decrease in removal efficiencies after 200 and $250 \mathrm{rpm}$ is may be due to stick a part of the biosorbent on the internal surface of the volumetric flask neck during the process of the shaker which lowers biosorptions of $\mathrm{MB}, \mathrm{MG}$ and $\mathrm{MV}$. Therefore, 250, 200 and $200 \mathrm{rpm}$ was taken as the optimum agitation speed as the maximum removal efficiencies can be obtained for $\mathrm{MB}, \mathrm{MG}$ and $\mathrm{MV}$ respectively in single system $(98 \%, 97.6 \%$, and 97.3$)$. These results are analogous to those reported by [29].

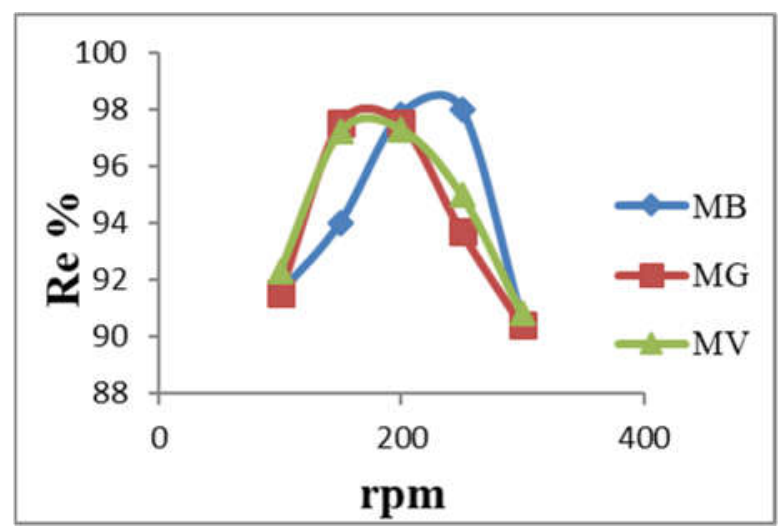

Figure 4: Removal efficiency of $\mathrm{MB}, \mathrm{MG}$, and $\mathrm{MV}$ biosorbed onto cork stopper particles at different agitation speeds $\left(\mathrm{pH}=3, \mathrm{C}_{\mathrm{o}}=50 \mathrm{mg} / \mathrm{l}, \mathrm{W}=(1,1.2) \mathrm{g}\right.$, time $=180 \mathrm{~min}$ and particle size $<1 \mathrm{~mm}$ ).

\subsection{Effect of biosorbent dose}

The effect of biosorbent doses on the removal efficiency of $\mathrm{MB}, \mathrm{MG}$, and MV was shown in fig.5. Which represents the relation between the removal efficiencies of $\mathrm{MB}, \mathrm{MG}$, and MV at different doses of cork stopper particles (0.11.4) g. For both MG and MV dyes the results demonstrate that the removal percentage is positively correlated with the amount of cork added. A rapid removal rate increases with the addition of cork when the dosage is less than 0.6 $\mathrm{g}$ and then the percentage removal increases slowly. When the amount of biosorbent added is $1.2 \mathrm{~g}$, the highest removal of $\mathrm{MG}$ and $\mathrm{MV}$ is almost reached $(97.5 \%$ and 96.8) respectively. An increase in adsorption may be concluded due to the increase in the adsorbent surface and, therefore, more active functional groups result in the availability of more adsorption sites [24].

The results of MB dye shown that the removal efficiency increase rapidly with the additional of cork up to $0.7 \mathrm{~g}$ then the removal efficiency decrease slowly with addition of cork particles. Consequently, $1.2 \mathrm{~g}$ was used as optimal amount for further experiments for $\mathrm{MG}$ and $\mathrm{MV}$ and $0.7 \mathrm{~g}$ for MB.

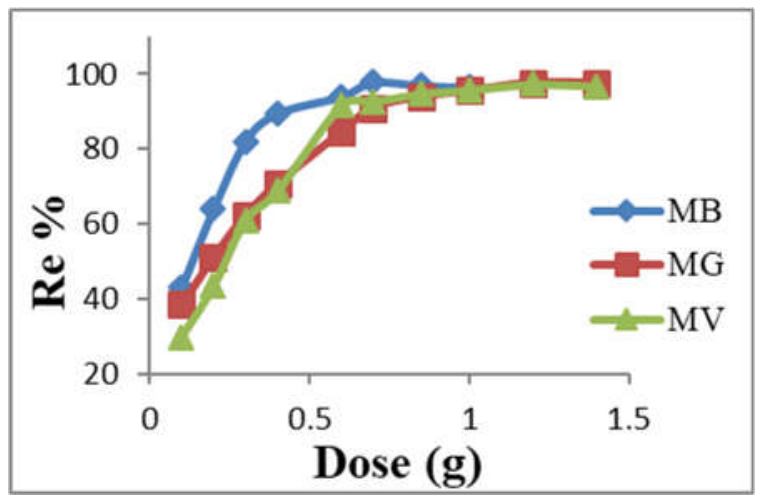

Figure 5: Removal efficiency of $\mathrm{MB}, \mathrm{MG}$, and $\mathrm{MV}$ biosorbed onto cork stopper particles at different doses of biosorbent $(\mathrm{Co}=50 \mathrm{mg} / \mathrm{l}, \mathrm{pH}=3$, time $=180 \mathrm{~min}, \mathrm{rpm}=$ 200, and particle size $<1 \mathrm{~mm}$ ).

\subsection{Effect of particle size}

The effect of particle size on the removal efficiency of MB, $\mathrm{MG}$, and $\mathrm{MV}$ is shown in fig. 6 .which represents the relation .between the removal efficiencies of $\mathrm{MB}, \mathrm{MG}$, and $\mathrm{MV}$ at different particle sizes $(0.11,0.274,0.55$, and $0.778) \mathrm{mm}$ were selected for batch adsorption experiments. It is found that the percentage removal of $\mathrm{MB}, \mathrm{MG}$, and MV increases with the reduction in the diameter of the particles. The decrease in the dyes removal with increase in the particle size is a result of decreased surface area of the adsorbent [14]. The maximum percentage elimination of $\mathrm{MB}, \mathrm{MG}$, and $\mathrm{MV} 98.48 \%, 98 \%$, and $98.5 \%$ respectively was reached using the fine particles $(\mathrm{d}=0.11$ $\mathrm{mm})$. 


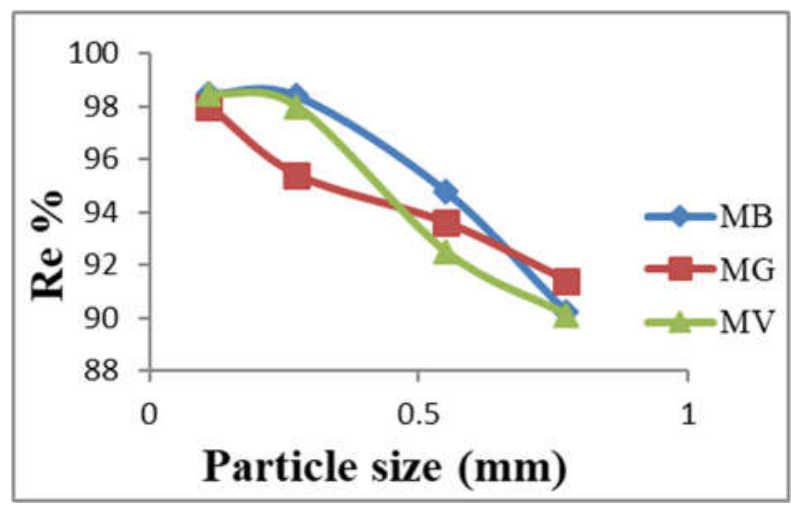

Figure 6: Removal efficiency of $\mathrm{MB}, \mathrm{MG}$, and $\mathrm{MV}$ biosorbed onto cork stopper particles in single system at different particles size of biosorbent $\mathrm{Co}=50 \mathrm{mg} / \mathrm{l}, \mathrm{pH}=3$, time $=240 \mathrm{~min}, \mathrm{rpm}=(200,200,250)$, and $\mathrm{W}=(0.7,1.2$, 1.2) $\mathrm{g}$.

\subsection{Sorption Isotherms}

Equilibrium data for the biosorption of MB, MG and MV dyes were analyzed with Langmuir, Freundlich and Temkin adsorption isotherm. The sorption data parameters for dyes onto cork stopper particles for each model were obtained by fitting the equations to the experimental data using Microsoft Excel as shown in Figures 6,7 , and 8 for Langmuir, Freundlich, and Temkin models respectively. Table (2) represents all parameters with correlation coefficient. From this tables the Langmuir model described sorption data slightly better than the other model depending on the value of coefficient of determination (R2).

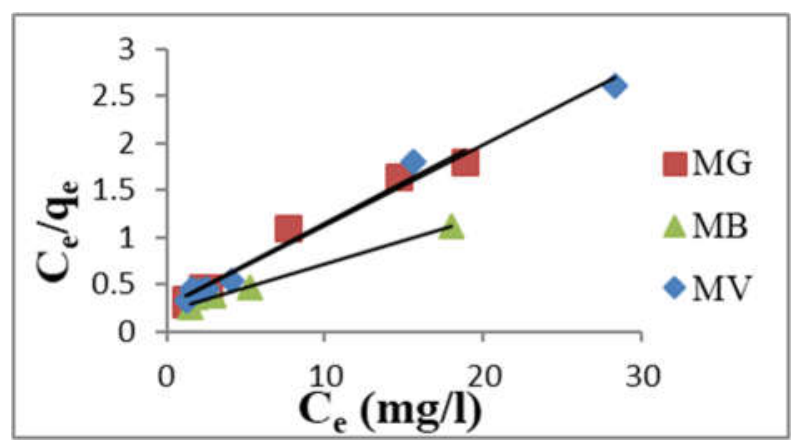

Figure 7: Langmuir isotherm model.

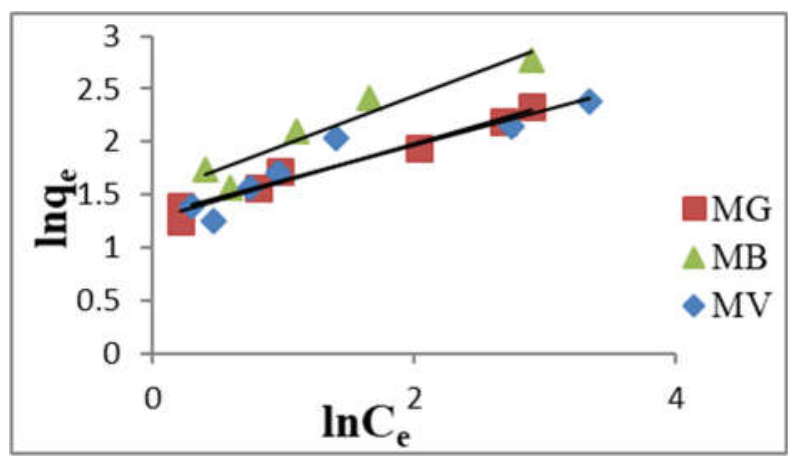

Figure 8: Freundlich isotherm model

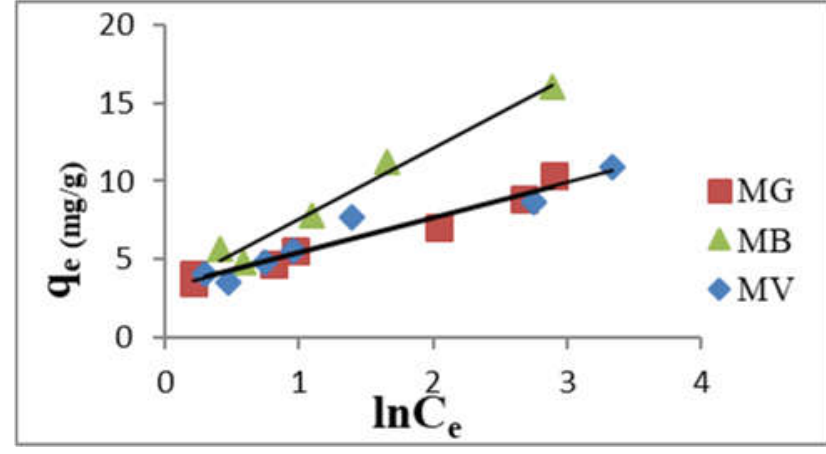

Figure 9: Temkin isotherm model

Table 2: Parameters of isotherm for MB, MG and MV onto cork stopper particles.

\begin{tabular}{|c|c|c|c|c|}
\hline Model & Parameters & MB & MG & MV \\
\hline \multirow{3}{*}{ Langmuir } & $\mathrm{q}_{\max }(\mathrm{mg} / \mathrm{g})$ & 20.4 & 11.3636 & 11.628 \\
\hline & $\mathrm{b}(\mathrm{l} / \mathrm{mg})$ & 0.177 & 0.3308 & 0.328 \\
\hline & $\mathrm{R}^{2}$ & 0.989 & 0.978 & 0.987 \\
\hline \multirow{3}{*}{$\begin{array}{l}\text { Freundlichi } \\
=\mathrm{K}_{\mathrm{f}} \mathrm{C}_{\mathrm{e}}^{1 / \mathrm{n}}\end{array}$} & $\mathrm{K}_{\mathrm{f}}(\mathrm{l} / \mathrm{g})$ & 4.459 & 3.5787 & 3.7099 \\
\hline & $\mathrm{n}$ & 2.132 & 2.8169 & 3.0211 \\
\hline & $\mathrm{R}^{2}$ & 0.917 & 0.972 & 0.875 \\
\hline \multirow{3}{*}{$\begin{array}{l}\text { Temkin } \\
\mathrm{qe}=(\mathrm{RT} / \mathrm{b}) \\
\ln \left(\mathrm{K}_{\mathrm{T}} \mathrm{Ce}\right)\end{array}$} & $\mathrm{K}_{\mathrm{T}}(1 / \mathrm{mg})$ & 1.974 & 4.1403 & 4.493 \\
\hline & $\begin{array}{c}\mathrm{B} 1=(\mathrm{RT} / \mathrm{b}) \\
(\mathrm{KJ} / \mathrm{mole})\end{array}$ & 4.524 & 2.234 & 2.201 \\
\hline & $\mathrm{R}^{2}$ & 0.977 & 0.964 & 0.930 \\
\hline
\end{tabular}

\subsection{FT-IR analyses}

The FT-IR spectra before and after biosorption of MB, MG and $\mathrm{MV}(\mathrm{Co}=50 \mathrm{mg} / 1, \mathrm{pH}=3, \mathrm{rpm}=(250,200,200)$ respectively, contact time $240 \mathrm{~min}$ at $(0.7,1.2,1.2) \mathrm{g}$ of cork stopper particles in a $100 \mathrm{ml}$ of $\mathrm{MB}, \mathrm{MG}$ and $\mathrm{MV}$ solutions were drawn to define the vibration frequency changes of the functional groups in the. biosorbents. The functional groups which were identified from the FT-IR spectra of the cork stopper particles are presented in Fig. 10 before loaded (pink), after loaded with MB (blue), after loaded with MG (red), and after loaded with MV (dark blue) and tabulated in Table 3. 


\subsection{Kinetic Experiment and Models}

\subsubsection{The optimum mass of cork stopper particles}

The mass of cork stopper particles used for biosorption of $\mathrm{MB}, \mathrm{MG}$ and MV was determined from the equilibrium related concentration of $(\mathrm{Ce} / \mathrm{Co}=0.05)$ " using Langmuir equation with mass balance in one liter of solution as follows:

$\mathrm{q}_{\mathrm{e}}=\frac{\mathrm{V}_{\mathrm{L}}\left(\mathrm{C}_{\mathrm{o}}-\mathrm{C}_{\mathrm{e}}\right)}{\mathrm{W}_{\mathrm{o}}}=\frac{\mathrm{q}_{\mathrm{m}} \mathrm{bCe}}{1+\mathrm{bC}_{\mathrm{e}}}$

Thus;

$\mathrm{W}_{\mathrm{o}}=\frac{\mathrm{V}_{\mathrm{L}}\left(\mathrm{C}_{\mathrm{o}}-\mathrm{C}_{\mathrm{e}}\right)\left(1+\mathrm{bC}_{\mathrm{e}}\right)}{\left(\mathrm{q}_{\mathrm{m}} \mathrm{bC}_{\mathrm{e}}\right)}$

The best mass of cork stopper particles was found to be (7.6, 9.2 and 9.1) g for "MB, MG and MV respectively.

\subsubsection{Optimum agitation speed}

Figures 11, 12, and 13 show the concentration decay curves of solutes at various agitation speeds of (200i, 400, 600 and 1000) rpm for MB, MG, and MV respectively. It was found that the optimum agitation speed to achieve $\mathrm{C} / \mathrm{Co}=0.05 \mathrm{i}$ was $400 \mathrm{i} \mathrm{rpm}$ for $\mathrm{MB}, \mathrm{MG}$, and $\mathrm{MV}$. It was clear that, if the speed was higher than 400 for $\mathrm{MB}, \mathrm{MG}$, and $\mathrm{MV}$, the equilibrium relative concentration was less than 0.05 .

The results indicated that Hydroxyl $(\mathrm{OH})$ and aromatic functional group plays an important role in the biosorption process.

\subsubsection{Determination of kinetic model coefficient}

The kinetic constants of each model were obtained using Microsoft Excel Software. Comparisons of the kinetic models; pseudo-first order, pseudo-second order, intraparticle diffusion, Fractional power, and Elovich results are depicted in figures 14, 15, 16, 17, and 18 and in Table 4.The results shows that pseudo second order model gives the best description for the experimental data (it have the highest value of R2).

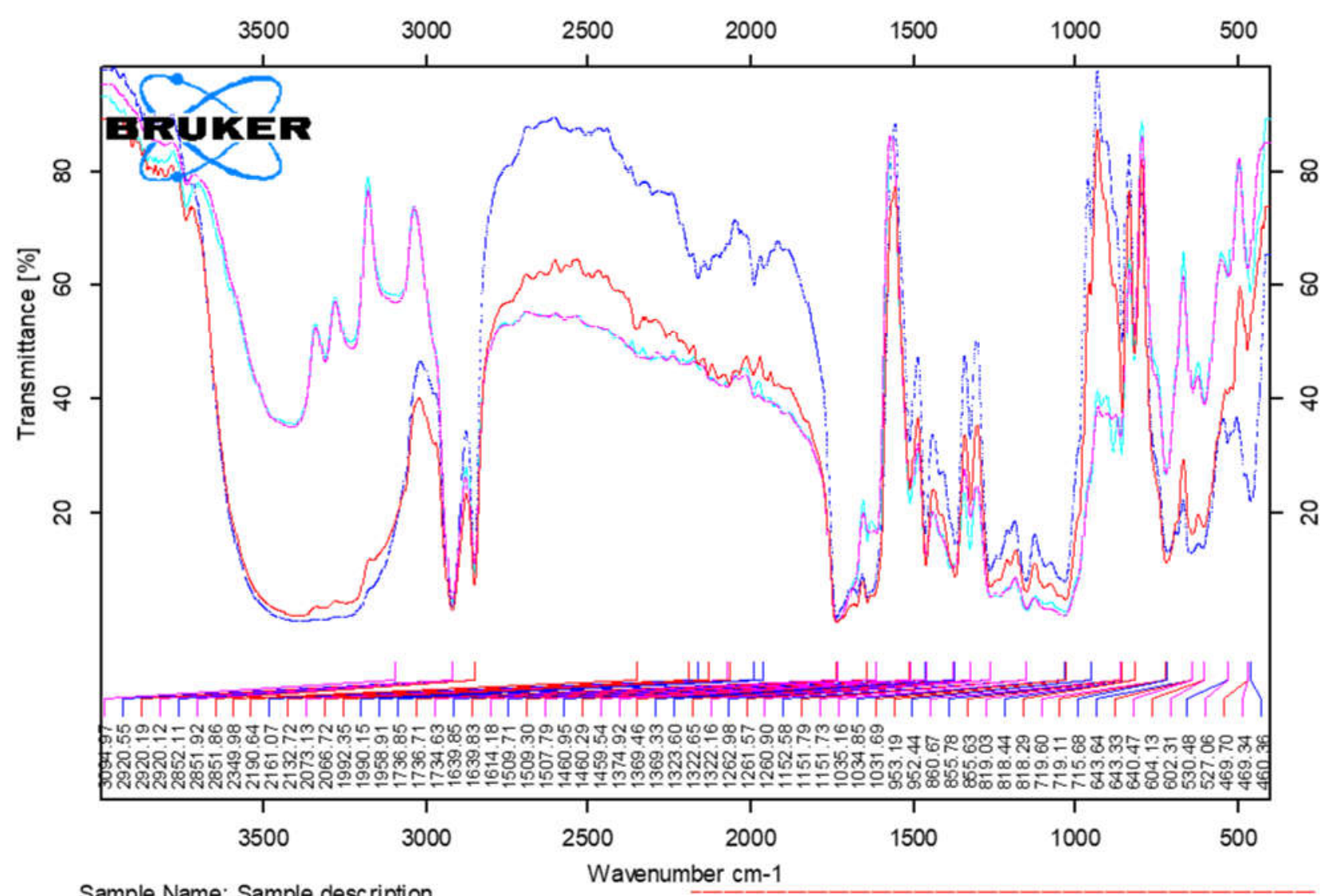

Sample Name: Sample description Sample Name: Sample description Sample Name: Sample description Sample Name: Sample description

Figure 10: FT-IR spectra for cork stopper particles before and after loaded with $50 \mathrm{mg} / \mathrm{l}$ of $\mathrm{MB}, \mathrm{MG}$, and $\mathrm{MV}$. 
Table 3: Functional groups responsible for MB, MG, and MV dyes biosorption onto cork stopper particles.

\begin{tabular}{|c|c|c|c|c|c|c|c|c|}
\hline \multirow{2}{*}{$\begin{array}{l}\text { FT-IR } \\
\text { Peak }\end{array}$} & \multirow{2}{*}{ Assignment groups } & \multirow{2}{*}{ Unloaded } & \multicolumn{3}{|c|}{ Loaded } & \multicolumn{3}{|c|}{ Difference in waves $\left(\mathrm{cm}^{-1}\right)$} \\
\hline & & & MB & MG & MV & MB & MG & MV \\
\hline 1 & Hydroxyl (OH) & 33409.01 & 3347.76 & 3395.38 & 3383.23 & 61.25 & 13.63 & 25.78 \\
\hline 2 & Alkane (C-H) & 2920.12 & 2920.71 & 2920.19 & 2920.55 & -0.59 & -0.07 & -0.43 \\
\hline 3 & Carbonyl $(\mathrm{C}=\mathrm{O})$ & 1734.63 & 1736.87 & 1736.71 & 1736.85 & -12.24 & -2.08 & -2.22 \\
\hline 4 & Carbonyl $(\mathrm{C}=\mathrm{O})$ & 1614.18 & 1599.64 & 1639.83 & 1639.85 & 14.54 & -25.65 & -25.67 \\
\hline 5 & Carbonyl $(\mathrm{C}=\mathrm{O})$ & 1507.79 & 1508.91 & 1509.30 & 1509.71 & -1.12 & -1.56 & -1.92 \\
\hline 6 & Carbonyl $(\mathrm{C}=\mathrm{O})$ & 1459.54 & 1458.64 & 1460.29 & 1460.95 & 0.9 & -30.75 & -1.41 \\
\hline 7 & Carboxylate (-COO$\left.{ }^{-}\right)$ & 1374.92 & 1328.62 & 1369.46 & 1369.33 & 46.3 & 5.46 & 5.59 \\
\hline 8 & Carboxylate $\left(-\mathrm{COO}^{-}\right)$ & 1260.90 & 1234.82 & 1261.57 & 1262.98 & 26.08 & -0.67 & -2.08 \\
\hline 9 & $\begin{array}{l}\text { Carpoxylic acids and } \\
\text { alcohol }(\mathrm{C}-\mathrm{O})\end{array}$ & 1151.73 & 1154.99 & 1151.79 & 1152.58 & 5.74 & -0.06 & -0.85 \\
\hline 10 & Aromatic Compound & 860.67 & 883.41 & 855.63 & 855.78 & -22.74 & 5.04 & 4.89 \\
\hline 11 & Aromatic Compound & 819.03 & 852.24 & 818.29 & 818.44 & -33.21 & 0.74 & 0.59 \\
\hline 12 & Aromatic Compound & 719.60 & 598.76 & 719.11 & 715.68 & 120.84 & 0.49 & 3.92 \\
\hline 13 & Aromatic Compound & 640.47 & 565.72 & 643.33 & 643.64 & 74.75 & -2.86 & -3.17 \\
\hline 14 & Aromatic Compound & 469.34 & 458.83 & 496.7 & 460.36 & 10.51 & -27.36 & 8.98 \\
\hline
\end{tabular}




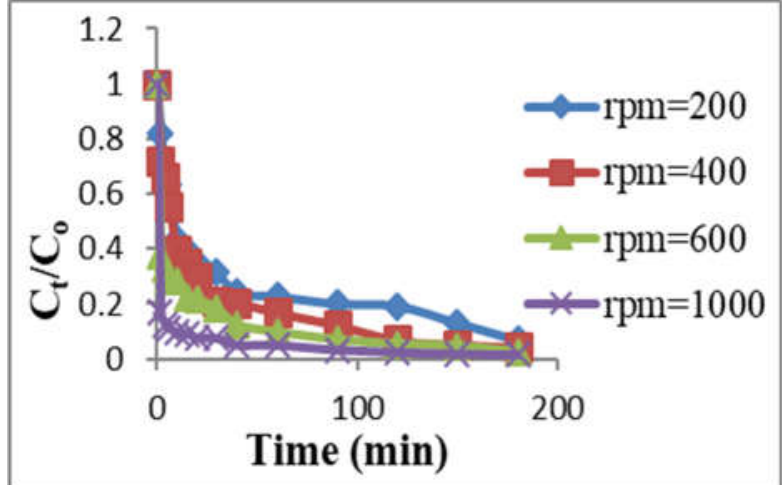

Figure 11: Concentration-time decay curves for biosorption of MB dye onto cork stopper particles in batch process at different agitation speeds $(\mathrm{Co}=50 \mathrm{mg} / \mathrm{l}$, time $=$ $180 \mathrm{~min}, \mathrm{Wo}=7.6 \mathrm{~g}, \mathrm{pH}=3$, and particle size $(\mathrm{d})=0.11$ $\mathrm{mm})$.

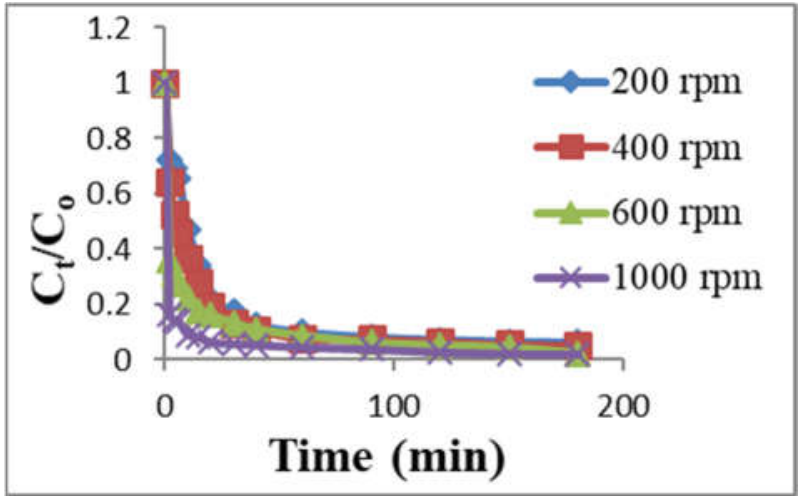

Figure 12: Concentration-time decay curves for biosorption of MG dye onto cork stopper particles in batch process at different agitation speeds $(\mathrm{Co}=50 \mathrm{mg} / \mathrm{l}$, time $=$ $180 \mathrm{~min}, \mathrm{Wo}=9.2 \mathrm{~g}, \mathrm{pH}=3$, and particle size $(\mathrm{d})=0.11$ $\mathrm{mm})$.

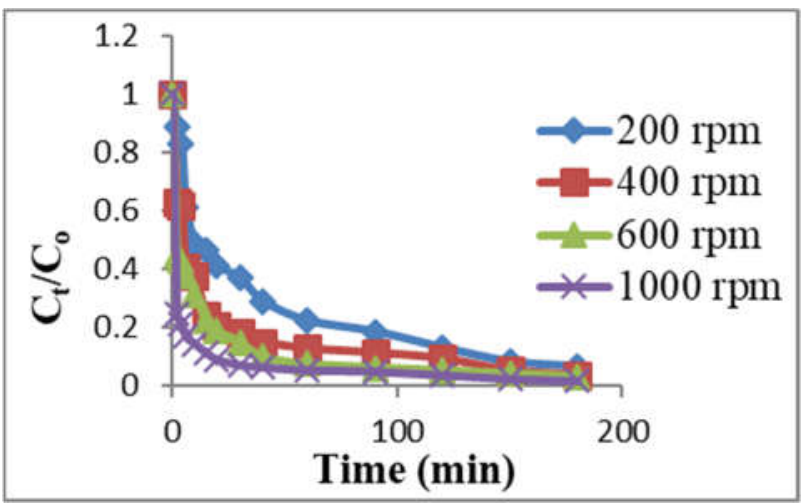

Figure 13: Concentration-time decay curves for biosorption of MV dye onto cork stopper particles in batch process at different agitation speeds $(\mathrm{Co}=50 \mathrm{mg} / \mathrm{l}$, time $=$ $180 \mathrm{~min}, \mathrm{Wo}_{\mathrm{o}}=9.1 \mathrm{~g}, \mathrm{pH}=3$, and particle size $(\mathrm{d})=0.11$ $\mathrm{mm})$.

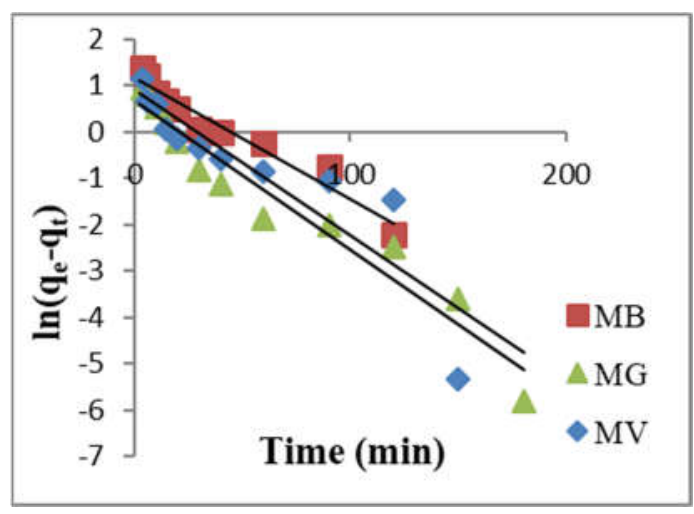

Figure 14: pseudo first order for biosorbtion of $M B, M G$ and MV onto cork stopper particles.

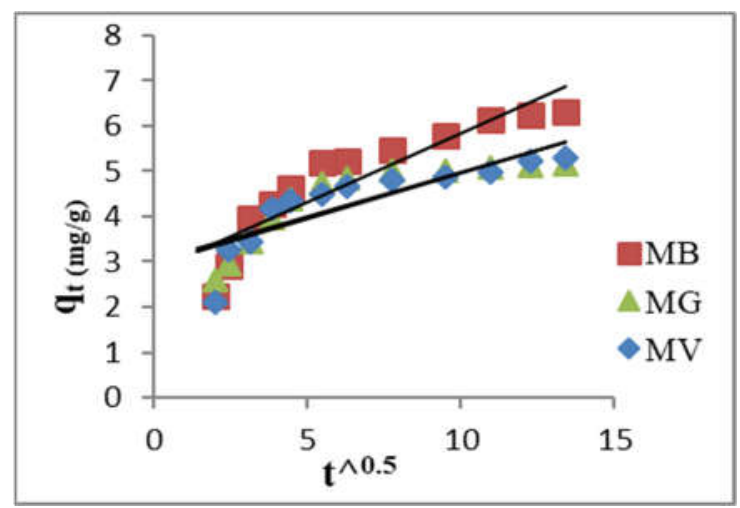

Figure 15: Intra-particle diffusion model for biosorption of MB, MG and MV onto cork stopper particles.

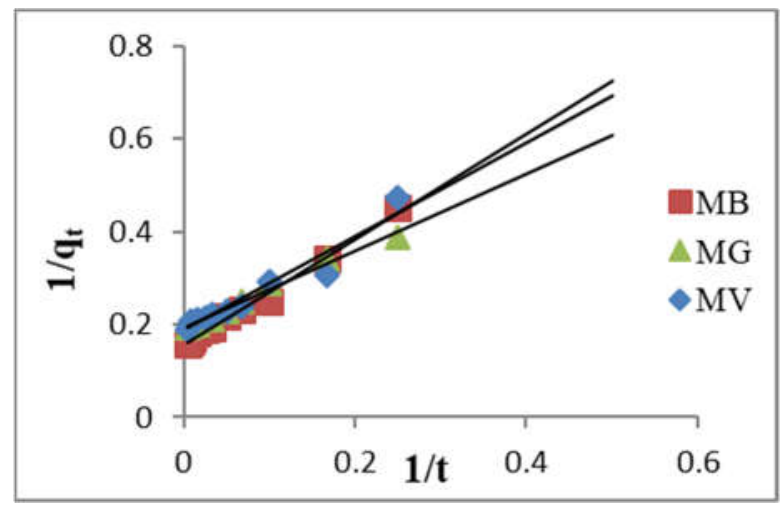

Figure 16: Pseudo second order for biosorption of MB, $\mathrm{MG}$, and MV onto cork stopper particles. 


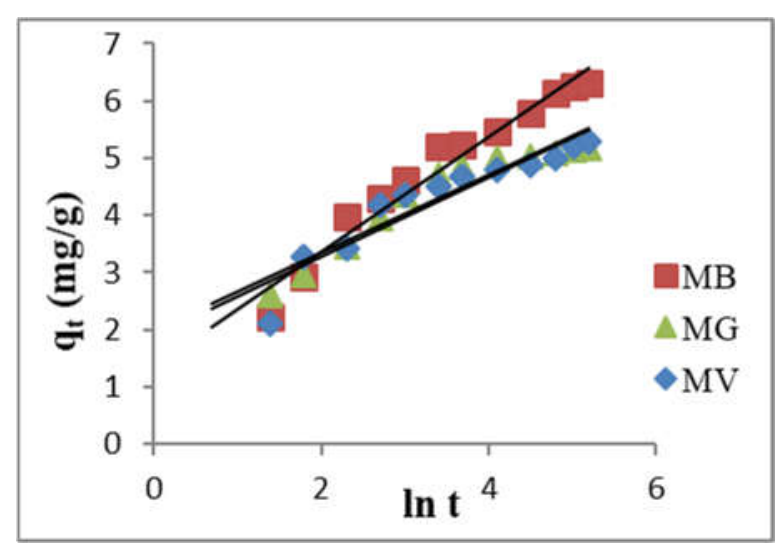

Figure 17: Elovich model for biosorption of $\mathrm{MB}, \mathrm{MG}$, and MV onto cork stopper particles.

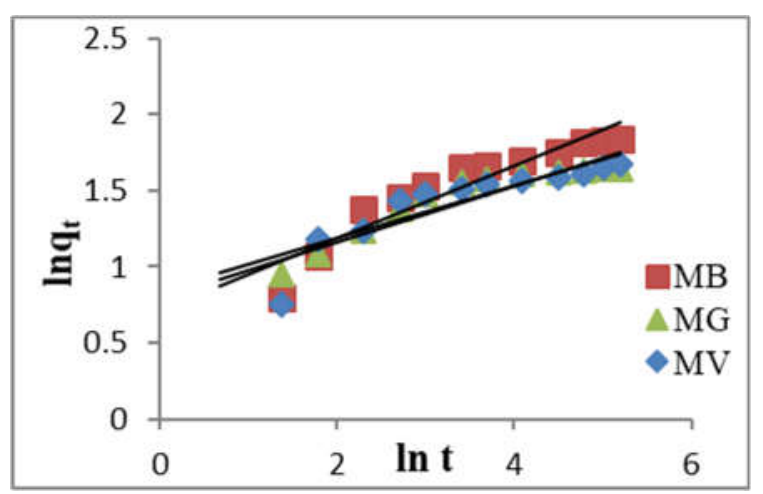

Figure 18: Fractional power model for biosorption of MB, $\mathrm{MG}$, and MV onto cork stopper particles.
Table 4: Functional groups responsible for $\mathrm{MB}, \mathrm{MG}$, and MV dyes biosorption onto cork stopper particles.

\begin{tabular}{|c|c|c|c|c|}
\hline Model & Parameters & MB & MG & MV \\
\hline \multirow{3}{*}{$\begin{array}{l}\text { Pseudo- } \\
\text { first-order }\end{array}$} & $\mathrm{q}_{\mathrm{e}}(\mathrm{mg} / \mathrm{g})$ & 3.238 & 1.912 & 2.413 \\
\hline & $\mathrm{K}_{\mathrm{L}}\left(\min ^{-1}\right)$ & 0.026 & 0.032 & 0.031 \\
\hline & $\mathrm{R}^{2}$ & 0.942 & 0.941 & 0.812 \\
\hline \multirow{3}{*}{$\begin{array}{l}\text { Pseudo- } \\
\text { second- } \\
\text { order }\end{array}$} & $\mathrm{q}_{\mathrm{e}}(\mathrm{mg} / \mathrm{g})$ & 6.452 & 5.263 & 5.405 \\
\hline & $\begin{array}{l}\mathrm{K}_{\mathrm{s}}(\mathrm{g} / \mathrm{mg} \cdot \mathrm{mi} \\
\mathrm{n})\end{array}$ & 0.0211 & $\begin{array}{l}0.043 \\
4\end{array}$ & $\begin{array}{l}0.033 \\
8\end{array}$ \\
\hline & $\mathrm{R}^{2}$ & 0.991 & 0.986 & 0.940 \\
\hline \multirow{3}{*}{$\begin{array}{l}\text { Intrapartic } \\
\text { le } \\
\text { diffusion }\end{array}$} & $\mathrm{C}(\mathrm{mg} / \mathrm{g})$ & 2.815 & 3.021 & 2.932 \\
\hline & $\begin{array}{l}\mathrm{K}_{\mathrm{id}}(\mathrm{mg} / \mathrm{g} \cdot \mathrm{mi} \\
\left.\mathrm{n}^{0.5}\right)\end{array}$ & 0.302 & 0.196 & 0.202 \\
\hline & $\mathrm{R}^{2}$ & 0.817 & 0.717 & 0.718 \\
\hline \multirow{3}{*}{ Elovich } & $\begin{array}{l}\mathrm{a} \\
(\mathrm{mg} / \mathrm{g} \cdot \mathrm{min})\end{array}$ & 3.947 & 2.608 & 2.562 \\
\hline & $\underline{b}(\mathrm{~g} / \mathrm{mg})$ & 0.994 & 1.477 & 1.447 \\
\hline & $\mathrm{R}^{2}$ & 0.955 & 0.901 & 0.883 \\
\hline \multirow{3}{*}{$\begin{array}{l}\text { Fractional } \\
\text { power }\end{array}$} & $\mathrm{K}(\mathrm{mg} / \mathrm{g})$ & 2.042 & 2.328 & $\begin{array}{l}2.203 \\
4\end{array}$ \\
\hline & $X\left(\min ^{-1}\right)$ & 0.236 & 0.172 & 0.184 \\
\hline & $\mathrm{R}^{2}$ & 0.878 & 0.863 & 0.794 \\
\hline
\end{tabular}

\section{Conclusions}

In this study, cork stopper particles were used as a natural, economic, and abundant biosorbent to remove $\mathrm{MB}, \mathrm{MG}$, and MV from simulated wastewater by biosorption process. The experimental results showed that the 
maximum removal efficiencies for $\mathrm{MB}, \mathrm{MG}$, and $\mathrm{MV}$ were $(98.48,98,98.5) \%$ respectively with an initial concentration of $50 \mathrm{mg} / \mathrm{l}, \mathrm{pH}$ value 3 , agitation speed (250, 200,200) rpm, $(0.7,1.2,1.2) \mathrm{g}$ of biosorbent and particle size $0.11 \mathrm{~mm}$ after $240 \mathrm{~min}$ contact time for $\mathrm{MB}, \mathrm{MG}$, and MV respectively. The equilibrium isotherm experiments were conducted and fitted with three models; Langmuir, Freundlich, and temkin. The biosorption were found to be of favorable type and Langmiur model gives the best fit to the experimental data with correlation coefficient equals to $(0.989,0.978,0.987)$ for $\mathrm{MB}, \mathrm{MG}$, and MV respectively. The kinetic experimental data were used to analyze the effect of external film boundary layer. Five kinetics models were investigated and fitted with "the experimental data. It was found that the kinetics of MB, MG, and MV biosorption onto cork stopper particles followed Pseudosecond order model for all three dyes.

\section{References}

[1] Abbas A., Razieh M., Tayyebeh M.,(2010), "Preconcentration and spectrophotometric determination of low concentrations of malachite green and leuco-malachite green in water samples by high performance solid phase extraction using maghemite nanoparticles.

[2] Adie, D.B., Okuofu, C.A., Osakwe, C., (2012), "Comparative analysis of the adsorption of heavy metals in wastewater using borrassus aethiopium and cocosnucifera', International Journal of Applied Science and Technology 2, 7,314-322.

[3] Ahmed, W. K., (2006), "Experimental and modeling for the removal of multi-pollutants by adsorption", $\mathrm{PhD}$. Thesis, College of Engineering, University of Baghdad.

[4] Alkan M., Do gan M., Colloid J. Interface Sci. 243 (2001) 280-291.

[5] Ai L., Zhou Y., Jiang J. (2011), Desalination 266 -72 .

[6] Allen S.J, Koumanova B.,(2005), Decolourisation of water /wastewater using adsorption (review), J. Univ. Chem. Technol. Metall. 40 (3) 175-192.

[7] Ariana, M.A., Catarina, I.A., Joana, C., Patr1', Susana, P., V1'tor, J.P., Cida, M.S., Rui, A.R., (2012), "Use of cork powder and granules for the adsorption of pollutants: A review", water research 46, 2, $3152-3166$.
[8] Aroso IV, Duarte ARC, Pires RR, Mano JF, Reis RL (2015) Cork processing with supercritical carbon dioxide: impregnation and sorption studies. J Supercrit Fluids 104:251-258

[9] Cherifi H., Fatiha B., Salah H., Appl. Surf. Sci. 282 (2013) 52.

[10] Cheung, W.H., and Mckay, G., (2003), "Kinetic analysis of the sorption of copper ions on chitosan", Journal of Chemical Technology and Biotechnology, 78, 562-571.

[11] Dominguesa, V., Alves, A., Cabral, M., DelerueMatos, C., (2005), "Sorption behaviour of bifenthrin on cork', Journal of Chromatography A 1069 (1), 127-132.

[12] Fernandes, E.M., Correlo, V.M., Chagas, J.A.M., Mano, J.F., Reis, R.L., (2010), “Cork based composites using polyolefin as matrix: morphology and mechanical performance", Composites Science and Technology 70 (16), 2310-2318.

[13] Ferreira J, Miranda I, S, en U, Pereira H (2016) Chemical and cellular features of virgin and reproduction cork from Quercus variabilis. Ind Crop Prod 94:638-648

[14] Fouad K. \& Omar el F. B., (2014), "Removal of methyl orange from aqueous solution via adsorption on cork as a natural and low-coast adsorbent: equilibrium, kinetic and thermodynamic study of removal process", Desalination and Water Treatment 53:37113723

[15] Ghosh D., Bhattacharyya K.G., (2002), "Adsorption of methylene blue on kaolinite", Appl. Clay Sci. 20: 295-300.

[16] Gulshan F., Yanagida S., Kameshima Y., Isobe T., Nakajima A., Okada K. 2010, Water Res. (44) $28-76$.

[17] Ho Y.S., (2004), "Citation review of Lagergren kinetic rate equation on adsorption reactions ", Scientometrics, 59, 171-177.

[18] Ho Y.S., Chiang T.H., Hsueh Y.M.,(2005), Removal of basic dye from aqueous solution using tree fern as a biosorbent, Proc. Biochem. 40 (1) 119-124. 
[19] Ho, Y.S. and McKay, G., (1999), "Pseudosecond order model for sorption processes ", Process Biochemical, 34, 451-465.

[20] Kazemi P., Peydayesh M., Bandegi A., Mohammadi T., Bakhtiari O.,(2013), Chem. Pap. 67 - 722.

[21] Krika, F., Azzouz, N., Ncibi, M., (2011), "Adsorptive removal of cadmium from aqueous solution by cork biomass: Equilibrium, dynamic and thermodynamic studies ", Arabian Journal of Chemistry.

[22] Lagorce-Tachon A, Karbowiak T, Champion D, Gougeon RD, Bellat JP (2015) Mechanical properties of cork: effect of hydration. Mater Design 82:148-154

[23] Liu Y., Kang Y., Mu B., Wang A. 2014, Chem. Eng. J. 237 - 403.

[24] Malekbala M.R., Hosseini S., Yazdi S.K., Soltani S.M., Malekbala M.R., (2012), the study of the potential capability of sugar beet pulp on the removal efficiency of two cationic dyes, Chem. Eng. Res. Des. 90: 704-712.

[25] Mesasa, L.M., Navarretea, R.E., Carrillo, F., Paleta, C., (2011), "Bioseparation of Pb (II) and Cd (II) from aqueous solution using cork waste biomass. Modeling and optimization of the parameters of the biosorption step", Chemical Engineering Journal, 174, 1, 9-17.

[26] Mittal A.K., Gupta S.K., (1996), Biosorption of cationic dyes by dead macro fungus Fomitopsis carnes: batch studies, Water Sci. Technol. 34 (10) $81-87$.

[27] Morshedi D., Mohammadi Z., Akbar Boojar M.M., Aliakbari F.,(2013), Colloids Surf., B:Biointerfaces 112 - 245.

[28] Parsons, J.J, (1962), "The cork oak forest and the evolution of the cork industry in southern Spain and Portugal', Econ. Geogr. 38, 195-214.

[29] Pehlivan, E. and Altun, T., (2008), "Biosorption of chromium (VI) ion from aqueous solutions using walnut, hazelnut and almond shell",
Journal of Hazardous Materials, 155, 1-2, 378384.

[30] Pereira, H., (2007), in Cork, Elsevier Science B.V., Amsterdam, 243-261.

[31] Pierce J.J. (1994), Colour in textile effluentsthe origins of problem, J. Soc. Dyers Color 110: 131-133.

[32] Pintor AMA, Ferreira CIA, Pereira JC, Correia P, Silva SP, Vilar VJP, (2012). Use of cork powder and granules for the adsorption of pollutants: A review. Water Res.; 46:3152-66.

[33] Raghu S., Lee C.W., Chellammal S., Palanichamy S., Basha C.A.(2009), Hazard J.. Mater. 171 - 748.

[34] Sachin, M. Kanawade and R.W.Gaikwad., (2011) "Removal of zinc ions from industrial effluent by using cork as adsorbent" international Jornal of chemical engineering and application.

[35] Shashi K., Deepak P., Pardeep S.,Pooja Dh., A., (2014), "Removal of malachite green and methylene blue by $\mathrm{Fe} 0.01 \mathrm{Ni} 0.01$ $\mathrm{Zn} 0.98 \mathrm{O} /$ polyacrylamide nanocomposite using coupled adsorption and photocatalysis", / Applied Catalysis B: Environmental 147: 340352

[36] Sirvastava, S.K., Tyagi, R., and Pant, N., (1989), "Adsorption of heavy metals on carbonaceous material developed from the waste slurry generated in local fertilizer plants", Water Res., $45,654-664$.

[37] Slokar Y.M., Le Marechal M. (1998), Methods of decoloration of textile wastewaters Dyes, Pigments 37: 335-357.

[38] Yang Z., Yang H., Jiang Z., Cai T., Li H., Li H., Li A., Cheng R. (2013), Hazard J.. Mater. (36) 254-255. 


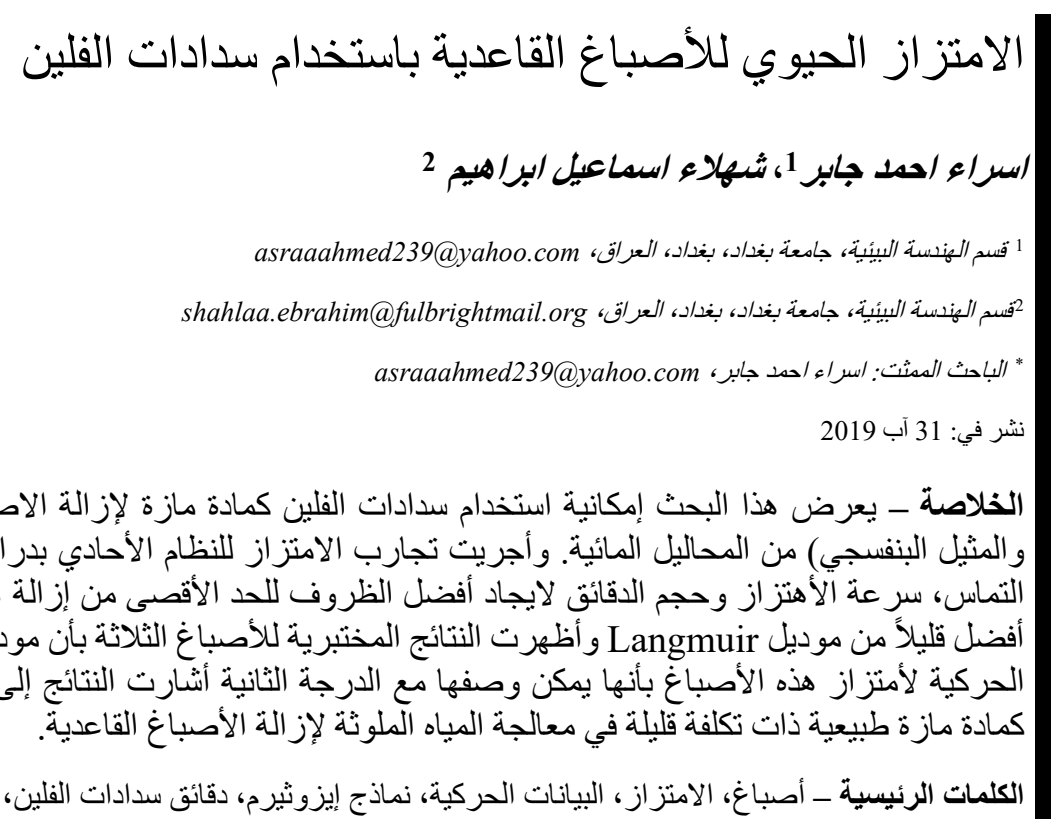

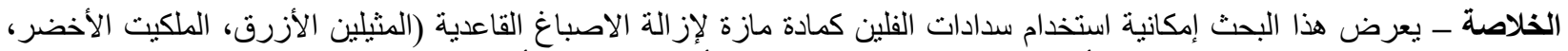

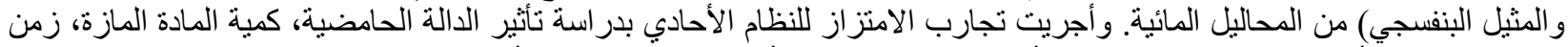

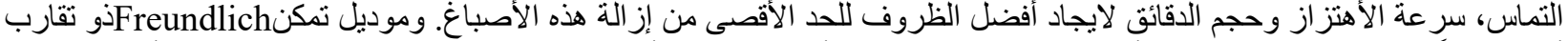

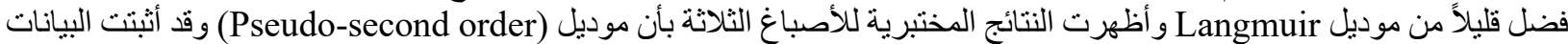

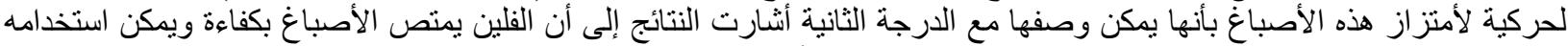
الكلمات الرئيسية ـ أصباغ، الامتز از، البيانات الحركية، نماذج إيزوثيرم، دقائق سدادات الفلين، المثيل البنفسجي، الملكيت الأخضر، المثيلين الأزرق. 